\title{
Methylobacterium salsuginis sp. nov., isolated from seawater
}

\author{
Xun Wang, Foday Sahr, Ting Xue and Baolin Sun
}

Correspondence

Baolin Sun

sunb@ustc.edu.cn
Hefei National Laboratory for Physical Sciences at Microscale and School of Life Sciences, University of Science and Technology of China, Hefei, Anhui 230027, People's Republic of China

\begin{abstract}
Three pink-pigmented, facultatively methylotrophic strains, designated MP1, MP2 and MR', were isolated from seawater from southern China and characterized. Analysis of their complete 16S rRNA gene sequences revealed that they constituted three separate phylogenetic groups, showing the highest levels of similarity with respect to some members of the genus Methylobacterium. PCR amplification also showed the gene coding for the $\alpha$-subunit of methanol dehydrogenase $(m x a F)$ to be present in all strains, indicating a methylotrophic metabolism. All three strains utilized D-fructose, ethanol and nutrient agar as carbon sources, but did not utilize sucrose, citrate, acetate or formaldehyde. On the basis of the phenotypic, phylogenetic and genotypic analyses, strain $\mathrm{MR}^{\top}$ represents a novel species, for which the name Methylobacterium salsuginis sp. nov. is proposed, with $\mathrm{MR}^{\top}$ (=CGMCC $1.6474^{\top}=$ NCCB $100140^{\top}$ ) as the type strain. Strains MP1 and MP2 respectively represent novel strains of the species Methylobacterium oryzae and Methylobacterium lusitanum.
\end{abstract}

Species of the genus Methylobacterium are strictly aerobic, facultatively methylotrophic, Gram-negative, rod-shaped bacteria that can grow on single-carbon compounds such as formate, formaldehyde and methanol as the sole source of carbon and energy, as well as on a wide range of multicarbon growth substrates (Green, 2006).

The genus Methylobacterium was initially proposed by Patt et al. (1976) with the type species Methylobacterium organophilum. The genus Methylobacterium belongs to the $\alpha-2$ subgroup of the Proteobacteria and consists of 23 species at the time of writing: Methylobacterium aminovorans (Urakami et al., 1993), Mtb. aquaticum (Gallego et al., 2005a), Mtb. chloromethanicum (McDonald et al., 2001), Mtb. dichloromethanicum (Doronina et al., 2000), $M t b$. extorquens (Bousfield \& Green, 1985), Mtb. fujisawaense (Green et al., 1988), Mtb. hispanicum (Gallego et al., 2005a), Mtb. lusitanum (Doronina et al., 2002), Mtb. mesophilicum (Green \& Bousfield, 1983), Mtb. nodulans (Jourand et al., 2004), Mtb. organophilum (Patt et al., 1976), Mtb. podarium (Anesti et al., 2004), Mtb. populi (Van Aken et al., 2004), Mtb. radiotolerans (Green \& Bousfield, 1983), Mtb. rhodesianum (Green et al., 1988), Mtb. rhodinum (Green \& Bousfield, 1983), Mtb. suomiense (Doronina et al., 2002), Mtb. thiocyanatum (Wood et al., 1998), Mtb. zatmanii (Green et al., 1988), Mtb. variabile (Gallego et al., 2005b), Mtb. isbiliense (Gallego et al., 2005c), Mtb.

The GenBank/EMBL/DDBJ accession numbers for the $m x a F$ and $16 S$ rRNA gene sequences of strain MP1 are EF030547 and EF015477, respectively, those for strain MP2 are EF030548 and EF015479, and those for strain $\mathrm{MR}^{\top}$ are EF030550 and EF015478. adhaesivum (Gallego et al., 2006) and Mtb. oryzae (Madhaiyan et al., 2007).

Several studies have reported the isolation of members of this genus from various natural environments (Green \& Bousfield, 1981, 1983), including soil, freshwater, tapwater systems, lake sediments and as contaminants in various products and processes. Their existence in tapwater systems has been attributed to their acquired resistance to chlorination (Hiraishi et al., 1995). More recently, strains of Methylobacterium have been associated with opportunistic urinary tract infection in immunocompromised persons (Lee et al., 2004). Here we report the isolation and characterization of a novel species and two novel strains of Methylobacterium isolated from seawater off the coast of southern China.

The methods used for enrichment and isolation were as described by Bodrossy et al. (1995) but with slight modifications. One litre of seawater obtained off the coast near Xiamen (Fujian Province) was concentrated using a polysulfone-fibre membrane with pore size of $0.22 \mu \mathrm{m}$. Aliquots $(20 \mu \mathrm{l})$ of the concentrated samples were added to $250 \mathrm{ml}$ flasks containing $50 \mathrm{ml}$ sterile mineral medium and were then incubated at $30{ }^{\circ} \mathrm{C}$ for 7 days. Serial dilutions of the active cultures were then spread onto $0.1 \mathrm{M}$ methanol mineral medium agar plates and incubated at $30{ }^{\circ} \mathrm{C}$ for 5-7 days. Individual colonies were isolated and purified by streaking several times onto similar agar plates. Only those cultures with a single type of morphology (as observed under light microscopy) were considered to be pure. 
Morphological characterization of the isolates included culture characterization on mineral salts media, Gramstaining and negative-staining for transmission electron microscopy. Cell growth at different $\mathrm{pH}$ values (5.0-10.0) and $\mathrm{NaCl}$ concentrations $(0.1-10.0 \%)$ was determined by measuring the $\mathrm{OD}_{600}$ using a spectrophotometer. Growth of the isolates at $4,28,30,32$ and $40{ }^{\circ} \mathrm{C}$ was also measured. Carbon-source utilization tests involving 12 carbon sources were performed by using a standard protocol described by Green \& Bousfield (1982). Biochemical characterization of the isolates included catalase, urease, indole, methyl red and Voges-Proskauer tests. Hydrolysis of starch and gelatin, hydrogen sulfide production, the Simmons' citrate test and nitrate-reduction tests were also performed using standard protocols.

Genomic DNA from the three strains was extracted and purified according to the methods described by Möller et al. (1992), with slight modifications. Primers 5'-AGAGTTTGATCCTGGCTCAG-3' and $5^{\prime}$-AAGGAGGTGATCCAGCC$3^{\prime}$, designed on the basis of previously published sequences of methanotrophic bacteria and synthesized by Invitrogen (Shanghai), were used as the forward and reverse primer, respectively, for $16 \mathrm{~S}$ rRNA gene amplification. The mxaF gene, encoding the methanol dehydrogenase required for methanol utilization, was detected by PCRs in these three strains, using primers $1003 \mathrm{f}$ ( $5^{\prime}$-GCGGCACCAACTGGGGCTGGT- $\left.3^{\prime}\right)$ and 1561r (5'-GGGCAGCATGAAGGGCTCCC-3') as described by Heyer et al. (2002).

PCR products of the 16S rRNA and mxaF genes were cloned in the pCR2.1 vector (Invitrogen) and submitted to Invitrogen for sequencing. The 16S rRNA gene sequences determined for our isolates were aligned, using RDP II (http://rdp.cme.msu.edu), with 16S rRNA gene sequences available for known Methylobacterium species, and the $m x a F$ gene sequences were aligned with reference sequences from GenBank by using BLAST (National Center for Biotechnology Information) and vector software. A phylogenetic tree was inferred by using the neighbour-joining (Saitou \& Nei, 1987) method with MEGA (version 3.1) software.

On the basis of the criteria of Bodrossy et al. (1995), three pure colonies were isolated and labelled MP1, MP2 and $\mathrm{MR}^{\mathrm{T}}$. On mineral medium agar plates, the three isolates produced pink, circular colonies, $1-4 \mathrm{~mm}$ in diameter. Gram-staining established them as Gram-negative rods that occurred as single cells or in rosettes. Negative staining followed by transmission electron microscopy showed that all three isolates had a rod-shaped morphology (Fig. 1). Their cells were strictly aerobic, catalase-positive, motile, lacked flagella and were able to produce urease. Indole and $\mathrm{H}_{2} \mathrm{~S}$ were not produced and the methyl red and VogesProskauer tests gave negative results. Further biochemical analysis showed the strains to be capable of hydrolysing starch but not gelatin. The results of Simmons' citrate tests and nitrate-reduction tests were also positive. Growth occurred at 28,30 and $32{ }^{\circ} \mathrm{C}$, but not at 4 or $40{ }^{\circ} \mathrm{C}$. For

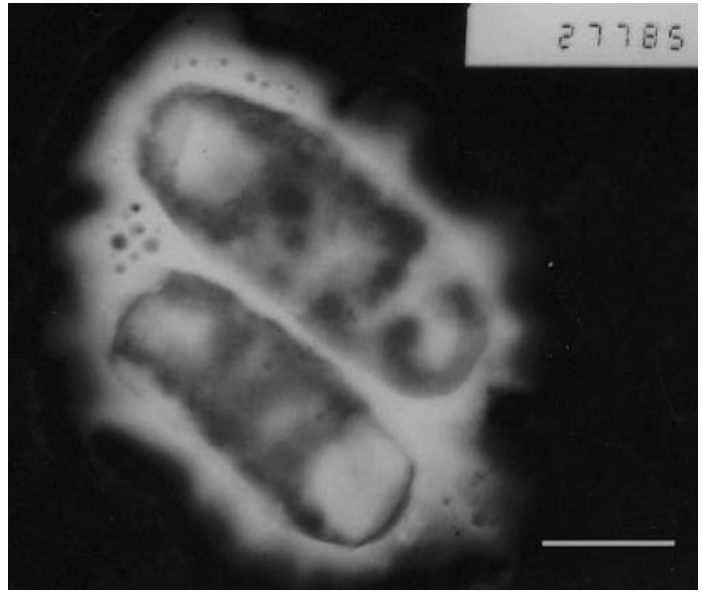

Fig. 1. Transmission electron micrograph of cells of strain $M^{\top}$, isolated from seawater samples. Bar, $2.0 \mu \mathrm{m}$.

strains MP1 and MP2, optimal growth occurred at $\mathrm{pH} 7$, whilst that for $\mathrm{MR}^{\mathrm{T}}$ occurred at $\mathrm{pH}$ 6. For strains MP1 and $\mathrm{MR}^{\mathrm{T}}$, no growth occurred in the presence of $\geqslant 1.5 \% \mathrm{NaCl}$; for MP2, growth inhibition occurred at $\geqslant 2 \% \mathrm{NaCl}$.

Analysis of the 16S rRNA gene sequences identified our isolates as three distinct strains of the genus Methylobacterium. Strains MP1 and MP2 were identified as novel strains of two previously characterized species of the genus, $M t b$. oryzae and Mtb. lusitanum, respectively, whereas strain $\mathrm{MR}^{\mathrm{T}}$ appeared to represent a novel species of this genus (Fig. 2). Because of the chemotaxonomic homogeneity of the genus Methylobacterium, phylogenetic analyses constitute a critical tool in species identification (Green \& Bousfield, 1982; Doronina et al., 2002). Strain MP1 had 96.3\% 16S rRNA gene sequence similarity with respect to a previously characterized strain of $M t b$. oryzae, whereas strain MP2 shared $98 \%$ sequence similarity with respect to a previously characterized strain of $M t b$. lusitanum. Strain $\mathrm{MR}^{\mathrm{T}}$ was found to be most closely related to $\mathrm{Mtb}$. suomiense $\mathrm{F} 20^{\mathrm{T}}$; however, the level of sequence similarity was only $93.1 \%$, suggesting that this strain represents a novel species of the genus Methylobacterium.

The gene for the $\alpha$-subunit of methanol dehydrogenase (mxaF) was amplified from strains MP1, MP2 and $\mathrm{MR}^{\mathrm{T}}$ and then sequenced. A comparison of the mxaF gene sequences of the three isolates showed varying levels of similarity. Strain MP1 showed $m x a F$ gene sequence similarities of 92.6 and $93.2 \%$ with respect to strain MP2 and strain $\mathrm{MR}^{\mathrm{T}}$, respectively, while strain MP2 showed $96.9 \% m x a F$ gene sequence similarity with respect to strain $\mathrm{MR}^{\mathrm{T}}$. When compared with representative Methylobacterium strains from the database, strain MP1 was most closely related to $M t b$. organophilum, with $93 \%$ mxaF gene sequence similarity. Strains MP2 and $\mathrm{MR}^{\mathrm{T}}$ were most closely related to $M t b$. podarium, with 97 and $96 \%$ sequence similarity, respectively. Analysis of the mxaF 


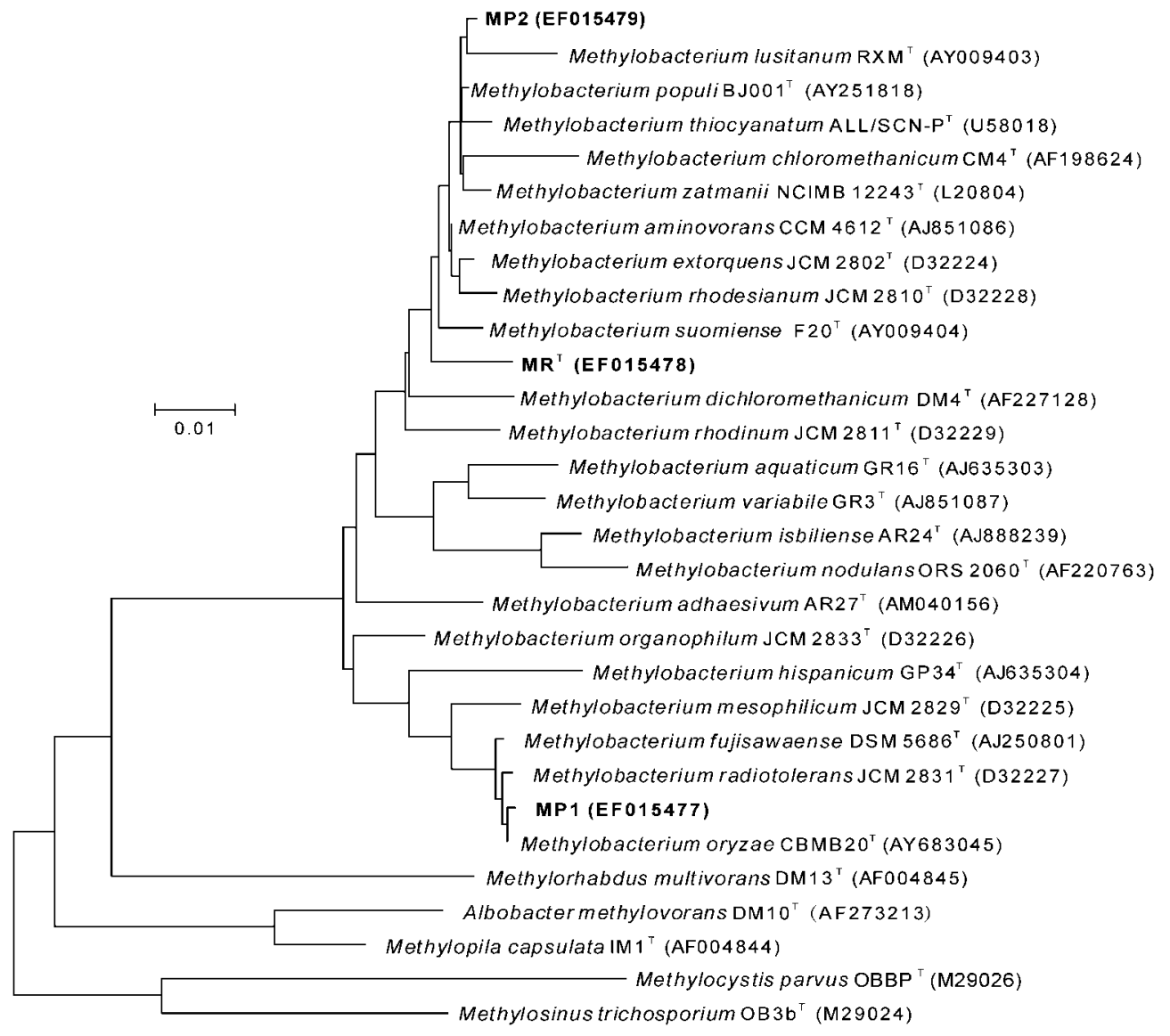

Fig. 2. Phylogenetic neighbour-joining tree, based on $16 \mathrm{~S}$ rRNA gene sequences, showing the relationships between strains MP1, MP2 and MR ${ }^{\top}$ and species belonging to the genus Methylobacterium and other related methylotrophic bacteria. Bar, $1 \%$ sequence divergence.

genes of our three strains confirmed the 16S rRNA gene sequencing results, indicating that MP1, MP2 and $\mathrm{MR}^{\mathrm{T}}$ belong to the genus Methylobacterium, exhibiting varying sequence similarity with respect to a number of previously characterized members of the genus (Table 1).

Three carbon sources, D-fructose, ethanol and nutrient agar, were utilized by all three strains. In comparisons between the carbon-source utilization profiles of previously characterized strains, strain MP1 and a previously characterized strain of $M t b$. oryzae were both able to utilize D-glucose, D-xylose, L-arabinose, fructose, ethanol and nutrient agar, but MP1 differed from its relative by not utilizing citrate or acetate as carbon sources. Strain MP2 and a previously characterized strain of Mtb. lusitanum also showed the ability to utilize D-fructose and ethanol. Strain MP2 was also able to utilize betaine, but was unable to utilize acetate, unlike the previously characterized strain of Mtb. lusitanum, which utilized acetate but not betaine. Strain $\mathrm{MR}^{\mathrm{T}}$ and its closest relative, $M t b$. suomiense, were both able to utilize D-glucose, D-fructose, betaine and ethanol. Strain $\mathrm{MR}^{\mathrm{T}}$ failed to utilize acetate, whilst its relative, $M t b$. suomiense, was able to utilize acetate as an energy source.
The phylogenetic data and several phenotypic features indicate that strain $\mathrm{MR}^{\mathrm{T}}$ represents a novel species and that strains MP1 and MP2 represent novel strains of Methylobacterium oryzae and Methylobacterium lusitanum, respectively. Strain $\mathrm{MR}^{\mathrm{T}}$ represents a novel species of the genus Methylobacterium, for which we propose the name Methylobacterium salsuginis sp. nov.

\section{Description of Methylobacterium salsuginis sp. nov.}

Methylobacterium salsuginis (sal.su'gi.nis. L. gen. n. salsuginis of brine, seawater).

Cells are Gram-negative rods, $1.0-1.5 \times 4.0-8.0 \mu \mathrm{m}$, occurring singly or in aggregates, and are strictly aerobic. Colonies are circular, regular in shape, pink to red, slowgrowing and $1-2 \mathrm{~mm}$ in diameter after $3-4$ days at $30{ }^{\circ} \mathrm{C}$ on methanol mineral medium agar plates. The pink pigment is water-insoluble. Catalase- and urease-positive, but negative for indole and in methyl red and VogesProskauer reactions. Simmons' citrate test is positive. Starch is hydrolysed, but gelatin is not. Hydrogen sulfide is 
Table 1. Differential phenotypic characteristics of strain $\mathrm{MR}^{\top}$, strains MP1 and MP2 and type strains of related Methylobacterium species

Strains: 1, Mtb. salsuginis sp. nov. $\mathrm{MR}^{\mathrm{T}}$; 2, Mtb. oryzae MP1; 3, Mtb. lusitanum MP2; 4, Mtb. aminovorans JCM $8240^{\mathrm{T}}$ (data from Urakami et al., 1993); 5, Mtb. suomiense NCIMB $13778^{\mathrm{T}}$ (Doronina et al., 2002); 6, Mtb. dichloromethanicum DSM 6343 ${ }^{\mathrm{T}}$ (Doronina et al., 2000); 7 , Mtb. thiocyanatum NCIMB $13651^{\mathrm{T}}$ (Wood et al., 1998); 8, Mtb. chloromethanicum NCIMB $13688^{\mathrm{T}}$ (McDonald et al., 2001). +, Positive; -, negative; w, weak growth; ND, no data available.

\begin{tabular}{|c|c|c|c|c|c|c|c|c|}
\hline Characteristic & 1 & 2 & 3 & 4 & 5 & 6 & 7 & 8 \\
\hline \multicolumn{9}{|l|}{ Cell arrangement } \\
\hline Single & + & + & + & + & + & + & ND & ND \\
\hline Pairs & + & Rarely & Rarely & Rarely & Rarely & Rarely & $\mathrm{ND}$ & ND \\
\hline Aggregates/rosettes & + & + & + & - & - & - & $\mathrm{ND}$ & ND \\
\hline \multicolumn{9}{|l|}{ Cell size } \\
\hline Length $(\mu \mathrm{m})$ & $4.0-8.0$ & $1.0-4.0$ & $2.0-3.0$ & $1.5-4.0$ & $1.2-2.5$ & $1.0-2.0$ & 2.0 & $2.5-3.5$ \\
\hline Width $(\mu \mathrm{m})$ & $1.0-1.5$ & $1.0-1.5$ & $0.8-1.0$ & $0.8-1.0$ & $0.8-1.0$ & $0.8-1.0$ & 0.8 & $0.8-1.0$ \\
\hline Pigmentation & Pink to red & Pink & Pink & Pink to red & Pink & Pink & Pink & Pink \\
\hline Colony diameter $(\mathrm{mm})$ & $1-2$ & $2-4$ & $1-2$ & $1-3$ & $0.5-1$ & $1-3$ & 1.5 & ND \\
\hline \multicolumn{9}{|l|}{ Growth on: } \\
\hline D-Glucose & + & + & - & - & + & - & + & - \\
\hline D-Xylose & - & + & - & - & - & - & $\mathrm{ND}$ & - \\
\hline L-Arabinose & - & + & - & $\mathrm{ND}$ & - & $\mathrm{ND}$ & $\mathrm{w}$ & ND \\
\hline D-Fructose & + & + & + & + & + & + & + & - \\
\hline Sucrose & - & - & - & $\mathrm{ND}$ & $\mathrm{ND}$ & $\mathrm{ND}$ & $\mathrm{ND}$ & ND \\
\hline Citrate & - & - & - & - & - & + & + & + \\
\hline Acetate & - & - & - & + & + & + & + & + \\
\hline Betaine & + & - & + & + & + & + & ND & + \\
\hline Ethanol & + & + & + & $\mathrm{ND}$ & + & $\mathrm{ND}$ & $\mathrm{ND}$ & ND \\
\hline Formaldehyde & - & - & - & ND & $\mathrm{ND}$ & $\mathrm{ND}$ & ND & ND \\
\hline Formate & + & - & + & ND & ND & ND & ND & ND \\
\hline Nutrient agar & + & + & + & ND & - & $\mathrm{ND}$ & + & ND \\
\hline
\end{tabular}

not produced. Nitrate is reduced to nitrite. Carbon sources utilized include D-fructose, D-glucose, methanol, ethanol, formate, betaine and nutrient agar. Does not utilize D-xylose, L-arabinose, sucrose, citrate, acetate or formaldehyde. Nitrogen sources utilized include ammonium and nitrate. Growth occurs at 28, 30 and $32{ }^{\circ} \mathrm{C}$ (optimum, $30{ }^{\circ} \mathrm{C}$ ) but not at 4 or $40{ }^{\circ} \mathrm{C}$. Growth occurs at pH 5.0-8.0 (optimum, pH 7.0). No growth occurs in the presence of $\geqslant 1.5 \% \mathrm{NaCl}$.

The type strain, $\mathrm{MR}^{\mathrm{T}}$ (=CGMCC $1.6474^{\mathrm{T}}=\mathrm{NCCB}$ $100140^{\mathrm{T}}$ ), was isolated from seawater collected off the coast of southern China, near Xiamen (Fujian Province).

\section{Acknowledgements}

The authors wish to thank Liang Tao for collecting the seawater sample and Yonglong Zhuang for his assistance with the transmission electron microscopy. This research was supported by the One Hundred Talent Project of the Chinese Academy of Sciences.

\section{References}

Anesti, V., Vohra, J., Goonetilleka, S., McDonald, I. R., Sträubler, B., Stackebrandt, E., Kelly, D. P. \& Wood, A. P. (2004). Molecular detection and isolation of facultatively methylotrophic bacteria, including Methylobacterium podarium sp. nov., from the human foot microflora. Environ Microbiol 6, 820-830.

Bodrossy, L., Murrell, J. C., Dalton, H., Kalman, M., Puskas, L. G. \& Kovacs, K. L. (1995). Heat-tolerant methanotrophic bacteria from the hot water effluent of a natural gas field. Appl Environ Microbiol 61, 3549-3555.

Bousfield, I. J. \& Green, P. N. (1985). Reclassification of bacteria of the genus Protomonas Urakami and Komagata 1984 in the genus Methylobacterium (Patt, Cole, and Hanson) emend. Green and Bousfield 1983. Int J Syst Bacteriol 35, 209.

Doronina, N. V., Trotsenko, Y. A., Tourova, T. P., Kuznetsov, B. B. \& Leisinger, T. (2000). Methylopila helvetica sp. nov. and Methylobacterium dichloromethanicum sp. nov., novel aerobic facultatively methylotrophic bacteria utilizing dichloromethane. Syst Appl Microbiol 23, 210-218.

Doronina, N. V., Trotsenko, Y. A., Kuznetsov, B. B., Tourova, T. P. \& Salkinoja-Salonen, M. S. (2002). Methylobacterium suomiense sp. nov. and Methylobacterium lusitanum sp. nov., aerobic, pink-pigmented, facultatively methylotrophic bacteria. Int J Syst Evol Microbiol 52, 773-776.

Gallego, V., Garcia, M. T. \& Ventosa, A. (2005a). Methylobacterium hispanicum sp. nov. and Methylobacterium aquaticum sp. nov., isolated from drinking water. Int J Syst Evol Microbiol 55, 281-287.

Gallego, V., Garcia, M. T. \& Ventosa, A. (2005b). Methylobacterium variabile sp. nov., a methylotrophic bacterium isolated from an aquatic environment. Int J Syst Evol Microbiol 55, 1429-1433. 
Gallego, V., García, M. T. \& Ventosa, A. (2005c). Methylobacterium isbiliense sp. nov., isolated from the drinking water system of Sevilla, Spain. Int J Syst Evol Microbiol 55, 2333-2337.

Gallego, V., Garcia, M. T. \& Ventosa, A. (2006). Methylobacterium adhaesivum sp. nov., a methylotrophic bacterium isolated from drinking water. Int J Syst Evol Microbiol 56, 339-342.

Green, P. N. (2006). Methylobacterium. In The Prokaryotes. A Handbook on the Biology of Bacteria, 3rd edn, vol. 5, pp. 257-265. Edited by M. Dworkin, S. Falkow, E. Rosenberg, K. H. Schleifer \& E. Stackebrandt. New York: Springer.

Green, P. N. \& Bousfield, I. J. (1981). The taxonomy of pink pigmented facultatively methylotrophic bacteria. In Microbial Growth on C1-Compounds, pp. 285-293. Edited by H. Dalton. London: Heyden \& Son.

Green, P. N. \& Bousfield, I. J. (1982). A taxonomic study of some Gram-negative facultatively methylotrophic bacteria. J Gen Microbiol 128, 623-638.

Green, P. N. \& Bousfield, I. J. (1983). Emendation of Methylobacterium Patt, Cole, and Hanson 1976; Methylobacterium rhodinum (Heumann 1962) comb. nov. corrig.; Methylobacterium radiotolerans (Ito \& Iizuka 1971) comb. nov., corrig.; and Methylobacterium mesophilicum (Austin \& Goodfellow 1979) comb. nov. Int J Syst Bacteriol 33, 875-877.

Green, P. N., Bousfield, I. J. \& Hood, D. (1988). Three new Methylobacterium species: M. rhodesianum sp. nov., M. zatmanii sp. nov., and M. fujisawaense sp. nov. Int J Syst Bacteriol 38, 124-127.

Heyer, J., Galchenko, V. F. \& Dunfield, P. F. (2002). Molecular phylogeny of type II methane-oxidizing bacteria isolated from various environments. Microbiology 148, 2831-2846.

Hiraishi, A., Furuhata, K., Matsumoto, A., Koike, K. A., Fukuyama, M. \& Tabuchi, K. (1995). Phenotypic and genetic diversity of chlorineresistant Methylobacterium strains isolated from various environments. Appl Environ Microbiol 61, 2099-2107.

Jourand, P., Giraud, E., Be'na, G., Sy, A., Willems, A., Gillis, M., Dreyfus, B. \& de Lajudie, P. (2004). Methylobacterium nodulans sp. nov., for a group of aerobic, facultatively methylotrophic, legume root-nodule-forming and nitrogen-fixing bacteria. Int J Syst Evol Microbiol 54, 2269-2273.
Lee, C.-H.., Tang, Y. F. \& Lin, J. W. (2004). Underdiagnosis of urinary tract infection caused by Methylobacterium species with current standard processing of urine culture and its clinical implications. J Med Microbiol 53, 755-759.

Madhaiyan, M., Kim, B. Y., Poonguzhali, S., Kwon, S. W., Song, M. H., Ryu, J. H., Go, S. J., Koo, B. S. \& Sa, T. M. (2007). Methylobacterium oryzae sp. nov., an aerobic, pink-pigmented, facultatively methylotrophic, 1-aminocyclopropane-1-carboxylate deaminase-producing bacterium isolated from rice. Int J Syst Evol Microbiol 57, 326-331.

McDonald, I. R., Doronina, N. V., Trotsenko, Y. A., McAnulla, C. \& Murrell, J. C. (2001). Hyphomicrobium chloromethanicum sp. nov. and Methylobacterium chloromethanicum sp. nov., chloromethaneutilizing bacteria isolated from a polluted environment. Int J Syst Evol Microbiol 51, 119-122.

Möller, E. M., Bahnweg, G., Sandermann, H. \& Geiger, H. H. (1992). A simple and efficient protocol for isolation of high molecular weight DNA from filamentous fungi, fruit bodies, and infected plant tissues. Nucleic Acids Res 20, 6115-6116.

Patt, T. E., Cole, G. C. \& Hanson, R. S. (1976). Methylobacterium, a new genus of facultatively methylotrophic bacteria. Int J Syst Bacteriol 26, 226-229.

Saitou, N. \& Nei, M. (1987). The neighbor-joining method: a new method for reconstructing phylogenetic trees. Mol Biol Evol 4, 406-425.

Urakami, T., Araki, H., Suzuki, K. \& Komogata, K. (1993). Further studies of the genus Methylobacterium and description of Methylobacterium aminovorans sp. nov. Int J Syst Bacteriol 43, 504-513.

Van Aken, B., Peres, C. M., Doty, S. L., Yoon, J. M. \& Schnoor, J. L. (2004). Methylobacterium populi sp. nov., a novel aerobic, pinkpigmented, facultatively methylotrophic, methane-utilizing bacterium isolated from poplar trees (Populus deltoides $\times$ nigra DN34). Int J Syst Evol Microbiol 54, 1191-1196.

Wood, A. P., Kelly, D. P., McDonald, I. R., Jordan, S. L., Morgan, T. D., Khan, S., Murrell, J. C. \& Borodina, E. (1998). A novel pinkpigmented facultative methylotroph, Methylobacterium thiocyanatum sp. nov., capable of growth on thiocyanate or cyanate as sole nitrogen sources. Arch Microbiol 169, 148-158. 